Respiraiion

\title{
Optoelectronic Plethysmography in Clinical Practice and Research: A Review
}

\author{
Carlo Massaroni $^{\mathrm{a}}$ Elena Carraro ${ }^{\mathrm{b}}$ Andrea Vianello ${ }^{c}$ Sandra Miccinilli ${ }^{\mathrm{d}}$ \\ Michelangelo Morrone $^{d}$ Irisz K. Levai ${ }^{e}$ Emiliano Schena ${ }^{a}$ Paola Saccomandi ${ }^{a}$

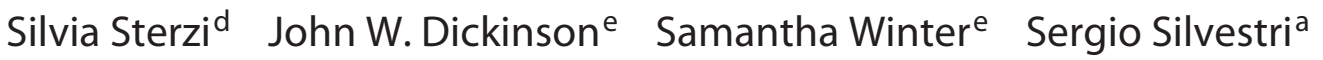 \\ ${ }^{a}$ Research Unit of Measurements and Biomedical Instrumentation, Campus Bio-Medico di Roma University, \\ Rome, ${ }^{b}$ F. Fabbri Posture and Motion Analysis Laboratory, Scientific Institute Eugenio Medea - La Nostra Famiglia \\ Association, Conegliano, 'Respiratory Pathophysiology Division, University-City Hospital of Padova, Padova, and

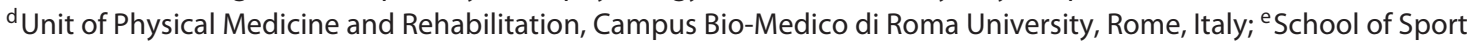 \\ and Exercise Sciences, University of Kent, Chatham Maritime, UK
}

\section{Keywords}

Optoelectronic plethysmography $\cdot$ Breathing $\cdot$ Mechanics of breathing $\cdot$ Respiratory volumes · Chest wall kinematic . Lung volumes

\begin{abstract}
Background: Optoelectronic plethysmography (OEP) is a non-invasive motion capture method to measure chest wall movements and estimate lung volumes. Objectives: To provide an overview of the clinical findings and research applications of OEP in the assessment of breathing mechanics across populations of healthy and diseased individuals. Methods: A bibliographic research was performed with the terms "opto-electronic plethysmography," "optoelectronic plethysmography," and "optoelectronic plethysmograph" in 50 digital library and bibliographic search databases resulting in the selection of 170 studies. Results: OEP has been extensively employed in studies looking at chest wall kinematics and volume changes in chest wall compartments in healthy subjects in relation to age, gender, weight, posture, and different physiological conditions. In infants, OEP has been demonstrated to be a tool to assess disease severi-
\end{abstract}

\section{KARGER}

(C) 2017 S. Karger AG, Basel

E-Mail karger@karger.com

www.karger.com/res ty and the response to pharmacological interventions. In chronic obstructive pulmonary disease patients, OEP has been used to test if patients can dynamically hyperinflate or deflate their lungs during exercise. In neuromuscular patients, respiratory muscle strength and chest kinematics have been analyzed. A widespread application of OEP is in tailoring post-operative pulmonary rehabilitation as well as in monitoring volume increases and muscle contributions during exercise. Conclusions: OEP is an accurate and validated method of measuring lung volumes and chest wall movements. OEP is an appropriate alternative method to monitor and analyze respiratory patterns in children, adults, and patients with respiratory diseases. OEP may be used in the future to contribute to improvements in the therapeutic strategies for respiratory conditions.

(c) 2017 S. Karger AG, Basel

\section{Introduction}

\section{Overview}

In clinical practice and scientific research, the evaluation of chest wall (CW) kinematics during breathing and the assessment of thoraco-abdominal volumes al- 
low an additional perspective on the study of different pathologies and can direct medical treatment during rehabilitation. From the middle of the 20th century, the scientific community started to study the respiratory system as a model [1-3] and founded its analysis on mechanical models of the different parts composing the system [3-6]. Mead et al. [7-9] published a series of scientific papers in which the possibility of measuring lung volume variations by the measure of thoracic and abdominal wall displacement was described. These studies led to hundreds of studies on respiratory mechanics in the 1980s with works of Mead et al. [10, 11], Hoppin et al. [4], Peslin et al. [6, 12], and others who contributed to the understanding of the respiratory drive and the mechanisms of pulmonary ventilation, and to the determination of how the ventilatory pump acts on respiratory structures.

The real technological breakthrough occurred in 1990 with Pedotti et al. $[13,14]$, who was the first to use a system based on motion analysis technology that provided the theoretical possibility of measuring and monitoring the movement of a number of points by photo-reflective markers. The ELITE system was the first motion analysis system used for the assessment of non-invasive optoelectronic breathing mechanics [14-16]. Since 2000, a growing number of studies have used optoelectronic plethysmography (OEP) to (a) assess breathing pattern, (b) measure asynchronies in breathing strategies in patients with various pathologies, and (c) investigate the healthy breathing biomechanics.

\section{Aim and Methods}

This paper provides an overview of the clinical findings and research applications of OEP in the non-invasive assessment of breathing in a population of healthy and diseased individuals and in a wide age range. In March 2016, a search in 50 Digital Library and Bibliographic Search databases (e.g., SCOPUS ${ }^{\circledR}$, PubMed $^{\circledR}$ and Google Scholar ${ }^{\circledR}$ ) with the terms "opto-electronic plethysmography," "optoelectronic plethysmography," and "optoelectronic plethysmograph" was performed. A total of 220 studies were found overall. After reading the titles and abstracts, those which referred to OEP were included, totalling 156 papers. After reading the full texts of these studies, 14 more studies were found by manual search. Thus, a total of 170 studies on OEP were selected.

\section{Working Principle: From 3D Marker Trajectories to Breathing Volumes}

OEP is a motion analysis system, which measures the changes of the CW during breathing by modelling the thoraco-abdominal surface. The OEP working principle is based on the general principles of 3D motion capture [17] (Fig. 1). OEP reconstructs the CW surface and then volume by placing a number of markers on the skin (Fig. 1). In a general clinical setting, 6- and 10-mm diameter hemispherical or spherical markers are used [34]. For standing evaluations, commonly an 89-marker protocol is used (as shown in Fig. 1, considered the "full marker" protocol) [18-24]. A 52-marker protocol can be used to assess subjects in the supine position, for example in the monitoring of breathing in intensive care [25-27]. A 24-marker protocol has been used to collect the upper and lower CW movements in the breathing analysis of newborn babies [28, 29]. Furthermore, a recent study validated a new 52-marker-based 3-compartment model of the CW to record spontaneous sleeping in infants [30].

A number of infrared (IR) cameras $(4[14,31-33]$ to 8 $[27,34,35])$ capture the scene and track a number of IRreflective markers within a previously calibrated volume [36] defining the recording workspace [37]. A dedicated workstation (Fig. 1) synchronizes input and output information to and from cameras; an ad hoc-designed software in the workstation computes the marker 3D trajectories integrating the information collected from each camera. Then, a geometrical model is applied: a closed surface is defined starting from connecting each triplet of markers to form a triangle. From each closed surface, the volume contained into this surface is calculated.

For each triangle - identified by 3 markers - the area $(\mathrm{S})$ and the direction of normal vector $(\vec{n})$ are calculated and from the volume contained in this surface can be calculated using the Gauss theorem $[14,38]$ as in equation (1):

$$
\int_{S} \vec{F} \cdot \vec{n} d S=\int_{V} d V=V,
$$

where $\vec{F}$ is an arbitrary vector, $S$ is a closed surface, $V$ is the volume enclosed by $S$, and $\vec{n}$ is the normal unit vector on $S$.

The OEP CW model can be divided into 3 compartments, composed of the pulmonary rib cage (RCp), the abdominal rib cage ( $\mathrm{RCa})$, and the abdomen $(\mathrm{AB})$ as highlighted in Figure 1. The 3-compartment model allows the following phenomena to be considered that (a) $\mathrm{RCp}$ and $\mathrm{RCa}$ are exposed at different pressures during the inspiration, (b) the diaphragm acts directly only on
340

Respiration 2017;93:339-354

DOI: $10.1159 / 000462916$
Massaroni et al. 
Fig. 1. Schematic of OEP working principle; 3D human chest wall reconstructed starting from 89 markers: blue, green, and red surfaces represent the pulmonary rib cage (RCp), the abdominal rib cage ( $\mathrm{RCa}$ ), and the abdomen $(\mathrm{AB})$, respectively. The rib cage ( $\mathrm{RC}$ ) volume is considered as the sum of RCp and RCa volumes. The plot shows the 3 compartmental volumes and the total chest wall volume during $60 \mathrm{~s}$ of OEP data collection in 1 healthy subject.

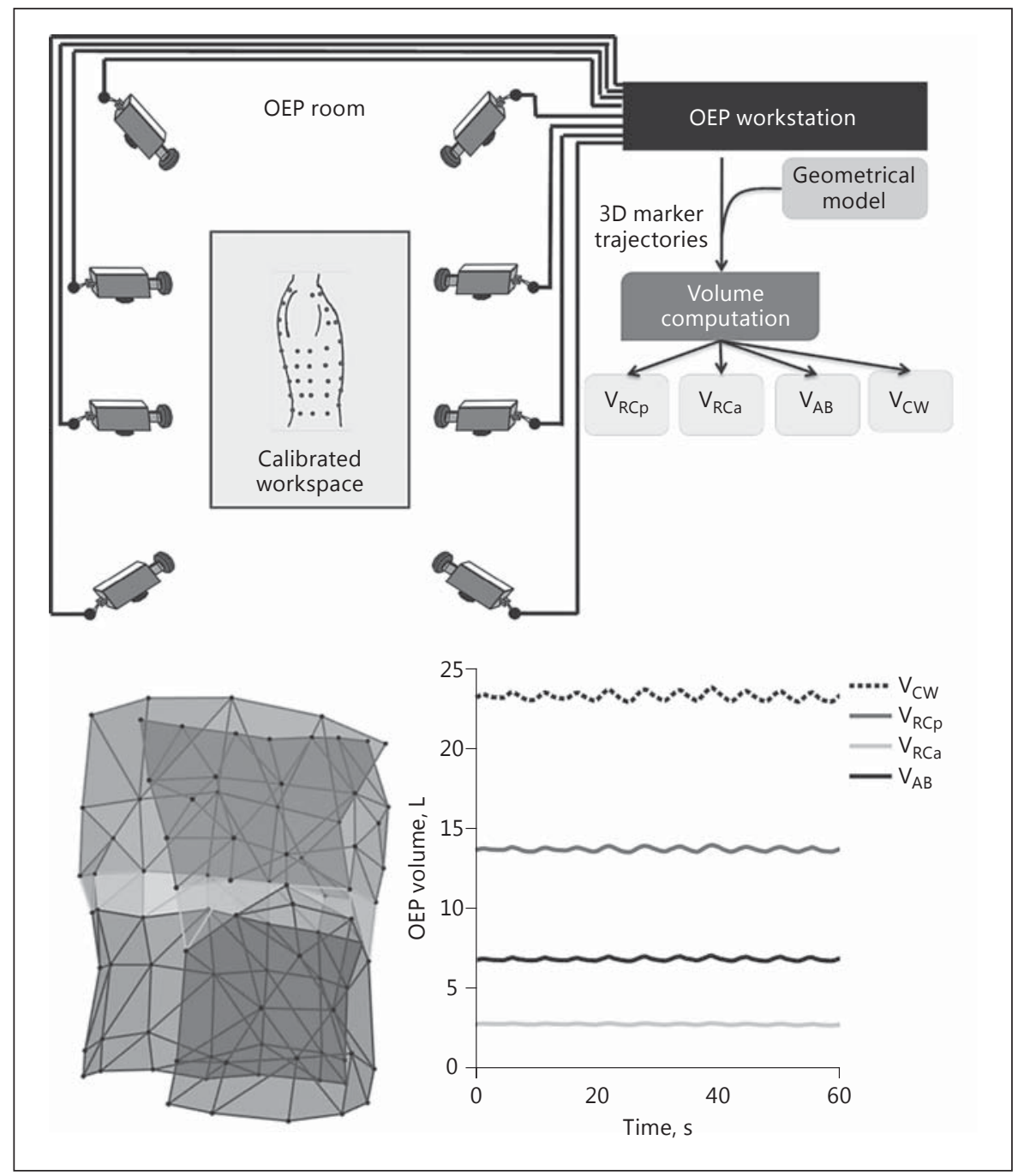

$\mathrm{RCa}$, and (c) non-diaphragmatic inspiratory muscles act largely on $\mathrm{RCp}$ and not on $\mathrm{RCa}$ [7]. Regarding the $\mathrm{AB}, \mathrm{AB}$ volume change is defined as the volume swept by the $\mathrm{ab}$ dominal wall $[7,24,39]$, and it is the result of the conjunct action of the diaphragm and expiratory abdominal muscles.

\section{OEP Applicability: What Does OEP Measure?}

\section{CW Kinematics}

$\mathrm{OEP}$ is a reliable tool for the analysis of CW kinematics partitioned into RCp, RCa, and AB, for both the left and right sides (also known as hemithoraxes). Results obtained from the breath-by-breath analysis of compartmental volumes can be further processed to assess if the thoraco-abdominal movement of the $\mathrm{CW}$ is synchronous, thus if $\mathrm{RC}$ (where $\mathrm{RC}=\mathrm{RCp}+\mathrm{RCa}$ ) and $\mathrm{AB}$ are moving in phase. When the 2 compartments move in opposite directions, paradoxical movement occurs [40]. Konno and Mead [7] described one of the first models of movement of the CW: in healthy subjects, volume variations of the rib cage must be equal and opposite to volume variations of the $\mathrm{AB}$, and the 2 compartments must move in phase. Several methods were designed in order to describe the synchrony of the thoraco-abdominal movement, also based upon ultrasound [41]. The most commonly used indexes are (a) the phase angle analysis and Lissajous loop evaluation [42-48], (b) the cross-correlation function [49], (c) the paradoxical inspiratory and expiratory time [50], (d) the inspiratory and expiratory phase ratio, and (e) the total phase ratio [50]. 


\section{Breathing Volumes}

The difference between the end-inspiratory volume and the end-expiratory volume is computed for each compartment, obtaining compartmental volumes. For each compartment, OEP gives information about the tidal volume $\left(\mathrm{V}_{\mathrm{T}}\right)[51]$ and end-expiratory and end-inspiratory volume $[39,52,53]$.

OEP can also indirectly compute the following pulmonary volumes: expiratory reserve volume, inspiratory reserve volume, forced expiratory volume in the first second $\left(\mathrm{FEV}_{1}\right)[54,55]$, vital capacity $(\mathrm{VC})$, and inspiratory capacity [56].

\section{Breathing Time Assessment}

By-breath analysis of compartmental volumes allows study of the respiratory cycle. The following variables are computed in order to analyze the respiratory cycle: inspiratory time $\left(\mathrm{T}_{\mathrm{i}}\right)$, expiratory time $\left(\mathrm{T}_{\mathrm{e}}\right)$, and total time of the respiratory cycle $\left(\mathrm{T}_{\text {tot }}\right)$, inspiratory time in relation to the total time $\left(\mathrm{T}_{\mathrm{i}} / \mathrm{T}_{\text {tot }}\right)$, minute ventilation $(\mathrm{MV})$, mean inspiratory flow $(\mathrm{VCcw} / \mathrm{Ti})$, and mean expiratory flow $\left(\mathrm{VC}_{\mathrm{CW}} /\right.$ $\mathrm{T}_{\mathrm{e}}$ ) [50].

\section{OEP Performance: Validity, Accuracy, and Reliability}

The accuracy of OEP has been assessed in different ways. OEP is typically able to detect linear marker displacements higher than $30 \mu \mathrm{m}$, which was assessed to be its threshold for detecting linear movement [57]. This results in a volume threshold around $9 \mathrm{~mL}$ for typical adults. The effects of number of cameras (i.e., 4, 6, 8) and marker size (i.e., spherical, 6- and 12-mm diameters) on OEP accuracy in linear displacement have been evaluated: increasing the number of cameras generally increases OEP accuracy if spherical $6 \mathrm{~mm}$ markers are used [57]. On the other hand, OEP accuracy in dynamic volume estimation appears not to be influenced by the magnitude of the thorax's movement [58]. The OEP volume accuracy investigated by a volume calibration device in the range of $0-2.78 \mathrm{~L}$ is always better than $6.0 \%$ of measured volume. The OEP volume standard deviation for a known volume change delivered via a volume calibration device 10 times was $\pm 2.7 \mathrm{~mL}$, in the range of $0-2.78 \mathrm{~L}$ [59].

The validity of OEP in measuring respiratory volume variations was performed by the comparison between $\mathrm{V}_{\mathrm{CW}}$ changes estimated by OEP, and lung volume variations measured by spirometers and pneumotachometers as gold standard instruments [60]. OEP validity has been evaluated in healthy seated and standing subjects with the 89-marker protocol in different experimental situations (e.g., quiet breathing, incremental exercises). The maximum difference between spirometer and OEP measurements was reported to be $<4 \%$ in all studies. $V_{C W}$ measurements of OEP, spirometry, and pneumotachography are highly correlated, with the mean discrepancy lower than $5 \%$, in constrained postures like supine and prone position in healthy subjects during quiet and deep breathing [61].

Intra-rater and inter-rater reliability of OEP has been evaluated at rest and during submaximal exercise on a cycle ergometer. OEP showed an intra-class correlation coefficient higher than 0.75 and a coefficient of variation always lower than $10 \%$ [62].

\section{Breathing Evaluation of Healthy Subjects}

In the last decade, OEP has been extensively employed in studies looking at CW kinematics and volume changes in the $3 \mathrm{CW}$ compartments in healthy subjects in relation to age, gender, weight, posture, and different physiological conditions, such as coughing and laughing.

In pre-term and term infants, OEP has been demonstrated as a good tool to assess lung volume and compartmental changes and relative compartmental distribution [28]. The main advantage of this technology is that subject collaboration is not necessary. Typically, an easier marker protocol (24 markers on the anterior thoraco-abdominal surface) is used for such analysis. The non-invasive bedside evaluation of the respiratory status with OEP is especially useful in critically ill neonates to assess disease severity and the response to pharmacological interventions [63] as well as to guide mechanical respiratory support (e.g., high-frequency oscillatory ventilation) [64].

In adulthood, OEP has been applied to study for the first time how the influence of posture and age can affect breathing variables (e.g., volumes, compartmental contribution to the $\mathrm{V}_{\mathrm{T}}$, breathing frequency). Aliverti et al. [16] demonstrated that during quiet breathing, the RCa volume changes are higher in the prone position; and $\mathrm{AB}$ volume changes have the opposite behaviour; they are decreased when subjects lay down. Volume data collected during deep breathing in healthy adults demonstrated that the distribution of compartmental breathing volumes is posture independent. The volume changes in both hemithoraxes are similar, as demonstrated by Nozoe et al. [65]. Moreover, Wang et al. [66] demonstrated that the motion of all $3 \mathrm{CW}$ compartments is highly correlated 
with diaphragmatic movement distance in the inspiratory phase during both quiet and deep breathing. In particular, the AB movement is closely correlated with diaphragmatic movement in the supine position. The progressively increased inclination of the trunk (from seated to supine position) determines a progressive reduction of RC displacement, $\mathrm{V}_{\mathrm{T}}$, and MV and a progressive increase in $A B$ contribution to the $V_{T}$ [67]. In a recent study, Souza Mendes et al. [68] demonstrated that posture, gender, and age influence both the breathing pattern and the thoraco-abdominal motion.

The influence of age on ventilatory kinematics and the mechanisms adopted by the elderly population to overcome age-related physiological changes has been studied by Muniz de Souza et al. [69]. They showed that in the elderly, during moderate inspiratory resistance, the pattern is deep and slow. With respect to the influence of gender, different results have been found in the literature. On one hand, Romei et al. [67] showed that female subjects are characterized by smaller dimensions of the RC compartment and during quiet breathing by lower $\mathrm{V}_{\mathrm{T}}$, minute ventilation and $\mathrm{AB}$ contribution to $\mathrm{V}_{\mathrm{T}}$ than males. On the other hand, Binazzi et al. [31] demonstrated no gender differences in breathing pattern or CW kinematics when normalized to size-related VC. Moreover, $\mathrm{Mu}$ niz de Souza et al. [69] investigated OEP differences in AB kinematics between young and elderly women during different inspiratory efforts. It was shown that in the elderly, the breathing pattern is deep and slow during moderate inspiratory resistance.

Barcelar et al. [70] investigated how both lung function and thoraco-abdominal volume variations during quiet breathing are altered in obese women. Obesity significantly reduced $\mathrm{V}_{\mathrm{RCp}}$ and increased $\mathrm{V}_{\mathrm{AB}}$ compared with normal weight. Additionally, the increased mass of $\mathrm{AB}$ modifies the position and the shape of the diaphragm, making this muscle more cranially displaced and its fibres lengthened.

New insights into OEP in the field of laughing and coughing have been gained. Filippelli et al. [71] highlighted that fits of laughter consistently lead to sudden and substantial decrease in lung volume in all the CW compartments and remarkable dynamic compression of the airways. Moreover, Cossette et al. [72] showed that flute support entails antagonistic contraction of non-diaphragmatic inspiratory muscles that tends to hold the RC at higher lung volume by collecting for the first time volume data with OEP in young professional flutists. OEP has been used to investigate the influence of cough on CW kinematics in healthy adults by Smith et al. [73] and

OEP in Clinical Practice and Research
Lanini et al. [19]. The operating volume was found to be the most important determinant of cough peak flow and volume expelled in healthy individuals [73]. A noticeable $\mathrm{RC}$ distortion ensues during coughing if the action of the muscle force acting on the $\mathrm{RCa}$ is not commensurate with the force acting on the RCp [19].

One study investigated the effect on the CW of the incentive spirometry in healthy adults [74], and Chihara et al. [80] analyzed the CW kinematics and respiratory muscle recruitment in 7 healthy men during rebreathing of a hypercapnic-hyperoxic gas mixture. The latter study showed that the end-inspiratory lung volume (EIV) increase in $\mathrm{V}_{\mathrm{CW}}$ was mainly achieved by increasing endinspiratory volumes of the RCp and RCa, reflecting the inspiratory RC muscle contribution to recruit the inspiratory reserve volume. Findings reported by Illi et al. [75] likely indicate that all inspiratory muscles fatigued simultaneously rather than in succession and that inspiratory $\mathrm{RC}$ muscles did not take over diaphragmatic work in the course of prolonged normocapnic hyperpnoea.

The comprehensive literature analysis reported in this section demonstrates that OEP can be considered both a reliable system for the basic physiological and pathophysiological studies thanks to its non-invasiveness measurements and no requirement of subject cooperation during the evaluations and an attractive tool for evaluating breathing under a wide variety of circumstances in health.

\section{Evaluation of Chronic Obstructive Pulmonary Disease Patients}

Although the origins of dyspnoea and exercise intolerance in chronic obstructive pulmonary disease (COPD) are complex and multifactorial, "dynamic hyperinflation" (DH), which is mainly due to expiratory flow limitation and gas accumulation/retention (usually termed "air trapping"), is presumably the most important factor in limiting exercise and contributing to dyspnoea by causing restrictive constraints onto volume expansion [76]. OEP has been used to confirm the hypothesis that COPD patients can dynamically hyperinflate or deflate lung/CW compartments during exercise. In one such study, Aliverti et al. [52] found that the patients with severe COPD showed $\mathrm{DH}$ during incremental exercise; patients with a greater expiratory flow reserve at rest, instead, adopted the more "normal" approach to reducing end-expiratory lung volume $(\mathrm{EEV})$ of the $\mathrm{CW}\left(\mathrm{EEV}_{\mathrm{CW}}\right)$ when they exercised.

Respiration 2017;93:339-354

DOI: $10.1159 / 000462916$ 
It remains nevertheless unclear if reduced lung volume contributes to relieving dyspnoea and improving exercise tolerance in COPD patients [77]. When Aliverti et al. [52] used OEP to analyze the effect of nebulized salbutamol on endurance exercise time in subjects with severe airway obstruction, they described 2 different response patterns to bronchodilation therapy: while the less hyperinflated patients showed reduced EEV after active treatment, the more severely hyperinflated ones continued to allow $\mathrm{EEV}_{\mathrm{AB}}$ to rise during exercise [78]. Georgiadou et al. [53] described an increase in exercise dyspnoea both in individuals who progressively hyperinflated the $\mathrm{CW}$ as well as in those who did not.

A lack of correlation between the degree of $\mathrm{DH}$ and exercise-induced dyspnoea has led to the hypothesis that abnormalities in CW motion, in particular, the paradoxical (inward) inspiratory movement of the lower rib cage, play a critical role in the onset of dyspnoea and exercise intolerance in COPD patients. OEP measurements have shown that although hyperinflated patients are especially likely to display abnormalities in RC motion, a paradoxical movement of the $\mathrm{RCa}$ is not entirely explained by static lung or dynamic RC hyperinflation [79-81].

Pursed-lip breathing (PLB), which involves nasal inspiration followed by exhalation through partially closed lips, has recently been used to assess volume changes in CW compartments and onset of dyspnoea in COPD patients. Bianchi et al. [82] utilized OEP measurement to analyze the displacement of the $\mathrm{CW}$ and its compartments and of the RC and $A B$ during supervised PLB manoeuvre in a group of patients with mild to severe COPD. Compared to spontaneous breathing, the patients practicing PLB exhibited a significant reduction in $\mathrm{EEV}_{\mathrm{CW}}$ and a significant increment in EIV of the CW.

The hypothesis that RC distortion plays a role in the onset of breathlessness during exercise in COPD patients raises the question if rehabilitation programs can reduce abnormalities in CW motion in these patients, thereby restoring exercise capacity and relieving breathlessness.

Gagliardi et al. [83] recently used OEP to evaluate the $\mathrm{V}_{\mathrm{CW}}, \mathrm{V}_{\mathrm{RC}}$, and $\mathrm{V}_{\mathrm{AB}}$ in COPD patients before and after a 24-session exercise program that included education, breathing retraining, unsupported arm exercise, and cycling. Study results showed that exercise training (a) had no effect on operational thoraco-abdominal volumes, (b) contributed to dyspnoea relief by improving patients' ventilatory profile, (c) increased tolerance to the dynamic restriction of CW volumes, and (d) improved RC distortion, albeit only to a small extent.
By using the OEP, Bruni et al. [84] evaluated the effect of oxygen therapy on dyspnoea, $\mathrm{CW} \mathrm{DH}$, and RC distortion in a group of COPD individuals. At isotime during exercise, while breathing supplemental oxygen, dyspnoea relief was associated with a decrease in ventilation regardless of whether patients distorted the RC or dynamically hyperinflated or deflated the CW. In the light of these results, the authors concluded that dyspnoea, CW DH, and $\mathrm{RC}$ distortion were not interrelated phenomena and that benefit from oxygen therapy was unrelated to its possible effect on RC distortion or dynamic CW hyperinflation.

When Coutinho Myrrha et al. [85] analyzed CW volumes and breathing patterns in COPD patients at rest and during inspiratory loaded breathing (ILB), they found that the $\mathrm{AB}$ was the main compartment responsible for $\mathrm{V}_{\mathrm{T}}$ during both situations. The authors noted that the COPD patients overcame the load imposed by ILB and improved $\mathrm{V}_{\mathrm{T}}$ by changing the inspiratory $\mathrm{V}_{\mathrm{CW}}$ without modifying the predominant mobility of the $\mathrm{AB}$ at rest and without affecting the $\mathrm{EEV}_{\mathrm{CW}}$.

Table 1 summarizes all the study utilizing OEP in the evaluation of patients with COPD.

\section{Use of OEP in Intensive Care Units}

The OEP system has been used to evaluate the effect of invasive and non-invasive ventilatory strategies on $\mathrm{V}_{\mathrm{T}}$ and thoraco-abdominal synchrony and to monitor CW mechanics and the distribution of $\mathrm{V}_{\mathrm{CW}}$ variations in patients undergoing mechanical ventilation. Aliverti et al. [29] found that volumes measured using OEP in patients with acute lung injury and acute respiratory distress syndrome receiving continuous positive pressure ventilation or pressure support ventilation (PSV) were highly correlated with measurements taken using spirometry and pneumotachography. They also assessed accuracy of the compartmentalization procedure ( $\mathrm{RCp}, \mathrm{RCa}$, and $\mathrm{AB}$ ) by calculating compartmental volume changes during isovolume manoeuvres, and concluded that OEP is able to provide relevant data on the distribution of $\mathrm{CW}$ volume variations in ventilated patients.

Dellacà et al. [86] set out to investigate the efficacy of OEP in assessing PEEP-induced variations of lung gas volume in mechanically ventilated, paralyzed patients with acute respiratory failure. The authors measured the EEV $_{\mathrm{CW}}$ breath-by-breath by OEP before, during, and after the PEEP increase/decrease and compared its variations with the corresponding EEV ones measured using the helium dilution technique. The regression line be-

Massaroni et al. 
Table 1. Studies utilizing OEP in the evaluation of patients with COPD

\begin{tabular}{|c|c|c|c|}
\hline First author [Ref.], year & $\begin{array}{l}\text { Pathology stage, sample } \\
\text { characteristics }\end{array}$ & Topic & Findings \\
\hline Aliverti [52], 2004 & Clinically stable, $n=20$ & $\begin{array}{l}\text { Pathogenesis of DH during } \\
\text { incremental exercise }\end{array}$ & $\begin{array}{l}\text { Response pattern may vary } \\
\text { according to disease severity }\end{array}$ \\
\hline Aliverti [78], 2005 & Severely obstructed, $n=18$ & $\begin{array}{l}\text { Effect of salbutamol on } \\
\text { endurance exercise }\end{array}$ & $\begin{array}{l}\text { Less hyperinflated patients show } \\
\text { reduced EELV }\end{array}$ \\
\hline Vogiatzis [123], 2005 & Clinically stable, $n=20$ & $\begin{array}{l}\text { Change in VT pattern during } \\
\text { recovery from exercise }\end{array}$ & $\begin{array}{l}\text { Presence of two patterns during } \\
\text { exercise: early and late } \\
\text { hyperinflation }\end{array}$ \\
\hline Georgiadou [53], 2007 & Severely obstructed, $n=20$ & $\begin{array}{l}\text { Influence of chest wall volumes } \\
\text { on dyspnoea during exercise }\end{array}$ & $\begin{array}{l}\mathrm{EEV}_{\mathrm{CW}} \text { attenuation in } \\
\text { "hyperinflators" does not reduce } \\
\text { dyspnoea }\end{array}$ \\
\hline Bianchi [114], 2007 & $\begin{array}{l}\text { Mild to severe obstruction, } \\
n=30\end{array}$ & $\begin{array}{l}\text { Volume changes in chest wall } \\
\text { compartments during PLB }\end{array}$ & $\begin{array}{l}\text { Symptom relief associated with } \\
\text { decreased end-expiratory } \\
\text { volumes of the chest wall and } \\
\text { abdomen in more severely } \\
\text { obstructed }\end{array}$ \\
\hline Bruni [84], 2012 & Clinically stable, $n=15$ & $\begin{array}{l}\text { Effect of oxygen therapy on } \\
\text { dyspnoea, chest wall DH, and rib } \\
\text { cage distortion }\end{array}$ & $\begin{array}{l}\text { Benefit unrelated to a possible } \\
\text { effect on rib cage distortion or } \\
\text { dynamic chest wall } \\
\text { hyperinflation }\end{array}$ \\
\hline $\begin{array}{l}\text { Coutinho Myrrha [85], } \\
2013\end{array}$ & Clinically stable, $n=13$ & $\begin{array}{l}\text { Chest wall volumes and } \\
\text { breathing patterns during ILB }\end{array}$ & $\begin{array}{l}\text { Increment in VT of the chest } \\
\text { wall as a result of higher } \\
\text { EEVCW during ILB }\end{array}$ \\
\hline Gagliardi [83], 2014 & Severely obstructed, $n=14$ & $\begin{array}{l}\text { Effect of exercise program on } \\
\text { chest wall volume, and } \\
\text { exercise-induced dyspnoea }\end{array}$ & $\begin{array}{l}\text { No effect on thoraco-abdominal } \\
\text { volumes; improved rib cage } \\
\text { distortion }\end{array}$ \\
\hline Rocha [115], 2015 & $\begin{array}{l}\text { Clinically stable with age }>60 \\
\text { years, } n=20\end{array}$ & $\begin{array}{l}\text { Effect of MDRT on } \\
\text { improvement of diaphragmatic } \\
\text { mobility }\end{array}$ & $\begin{array}{l}\text { MDRT significantly improved } \\
\text { diaphragmatic mobility over the } \\
\text { course of treatments and } \\
\text { significantly improved the 6-min } \\
\text { walk distance over the treatment } \\
\text { course }\end{array}$ \\
\hline Borges-Santos [116], 2015 & $\begin{array}{l}\text { Clinically stable, } n=54: 17 \text { no } \\
\text { symptoms, } 12 \text { anxiety } \\
\text { symptoms, } 13 \text { depressive } \\
\text { symptoms, } 12 \text { both symptoms }\end{array}$ & $\begin{array}{l}\text { Relationship between the } \\
\text { presence of symptoms of anxiety } \\
\text { or depression with breathing } \\
\text { pattern and thoraco-abdominal } \\
\text { mechanics at rest and during } \\
\text { exercise in COPD }\end{array}$ & $\begin{array}{l}\text { Patients with symptoms of } \\
\text { depression report more } \\
\text { dyspnoea. No impact of anxiety } \\
\text { and depression on breathing } \\
\text { pattern and thoraco-abdominal } \\
\text { mechanics }\end{array}$ \\
\hline Lima [117], 2016 & $\begin{array}{l}\text { Meta-analysis considering } 6 \\
\text { studies }\end{array}$ & $\begin{array}{l}\text { The effects of a constant load or } \\
\text { incremental cycle ergometer } \\
\text { tests on dyspnoea and CW } \\
\text { volumes }\end{array}$ & $\begin{array}{l}\text { Euvolumic COPD patients } \\
\text { respond more favourably with } \\
\text { less dyspnoea to constant load } \\
\text { and incremental protocol }\end{array}$ \\
\hline
\end{tabular}

DH, dynamic hyperinflation; EELV, end-expiratory lung volume; ILB, inspiratory loaded breathing; PLB, pursed-lip breathing; MDRT, manual diaphragm release technique; $\mathrm{EEV}_{\mathrm{CW}}$, end-expiratory lung volume (EEV) of the CW.

tween EEV changes measured by helium and $\mathrm{EEV}_{\mathrm{CW}}$ changes measured by OEP was found to be quite close to the identity line, and the difference was not related to their absolute magnitude.

Finally, OEP was used to study lung volume distribution during the administration of neurally adjusted ven- tilator assist (NAVA) ventilation, which assists spontaneous breathing proportionally to diaphragmatic electrical activity, compared to administration of PSV at different levels of support [87]. Although NAVA and PSV similarly reduced the abdominal contribution to $V_{T}$, subject-ventilator synchronization was better during 
NAVA with respect to PSV, and the difference between the 2 modes in regional ventilation distribution was not significant.

\section{OEP in the Neuromuscular Disease Evaluation}

Muscular diseases are characterized by progressive loss of muscle strength, resulting in cough ineffectiveness with its deleterious effects on the respiratory system. Assessment of cough effectiveness is, therefore, a prominent component of the clinical evaluation and respiratory care in these patients. Table 2 shows the main findings from studies performed on patients with neuromuscular diseases.

OEP has been used to investigate pulmonary volumes, respiratory muscle strength, peak cough flow, and CW kinematics in neuromuscular patients. A recent review suggests the use of OEP as a non-invasive method to study the thoraco-abdominal kinematics in children with neuromuscular diseases [88]. Subjects with these conditions are unable to reduce $\mathrm{EE}_{\mathrm{CW}}$ volume and exhibit greater RC distortion during cough. Peak cough flow is negatively correlated with $\mathrm{RC}$ distortion (the greater the former, the smaller the latter), but is not correlated with respiratory muscle strength [89]. So, this suggests that insufficient deflation of CW compartments and marked RC distortion resulted in cough ineffectiveness in these neuromuscular patients.

In patients with Duchenne muscular dystrophy (DMD), OEP highlighted that the $\mathrm{CW}$ motion during spontaneous breathing in awake conditions and in the supine position is an important indicator of the degree of respiratory muscle impairment in DMD [26]. Moreover, the contribution of abdominal volume change is a strong indicator of diaphragm impairment [90] such that it could discriminate between efficient end inefficient coughs $[91,92]$. However AB contribution is not only an important marker of the progression of the disease but is also an early indicator of nocturnal hypoxaemia [26]. Although, even in other dystrophic diseases as Becker muscular dystrophy, facioscapulohumeral dystrophy, and Limb-girdle dystrophy, OEP is able to reveal mild initial modifications in the respiration, which could be helpful for functional and new therapeutic strategy evaluation. Moreover, OEP has been used in spinal muscular atrophy (SMA) patients with the aim to investigate if the RC motion was similar in mild SMA (with onset of lower limbs muscular weakness after 3 years) and healthy subjects $[27$, 93].

\section{Outcome Assessment after Thoracic Surgery}

Thoracic surgery deeply affects CW kinematics, mainly in the early post-operative period. Patients who underwent surgical procedures involving the $\mathrm{CW}$ may benefit from pulmonary rehabilitation (PR) in order to restore correct function of respiratory muscles [94]. OEP represents a suitable tool to identify muscular dysfunctions related to chest surgery.

Lung transplantation (LT) represents the most burdensome CW dynamics' alteration surgical procedures. Wilkens et al. [95] utilized OEP to measure CW volumes of 39 patients affected by COPD, idiopathic pulmonary fibrosis and cystic fibrosis (CF), waiting for LT, and 16 transplanted subjects. Three distinctive breathing patterns were observed to cope with the disease, which includes higher $V_{T}$ due to increased EIV for COPD and increased respiratory rate without $\mathrm{V}_{\mathrm{T}}$ changes in $\mathrm{CF}$ and pulmonary fibrosis patients. Chronic adaptations of the ventilatory pump to advanced lung diseases seem to be reversible, as the authors demonstrate that LT restores a normal breathing pattern regardless of the underlying disease. Nosotti et al. [96] focused the attention on the rearrangement of the $\mathrm{V}_{\mathrm{CW}}$ and its compartments in $\mathrm{CF}$ patients receiving a double LT. Results showed that 2 months after surgery, total lung capacity, functional residual capacity, and residual volume significantly decrease, mainly due to the reduction in $\mathrm{AB}$ amplitude and to a lesser extent in RCp displacement. Based on these findings, the authors argued that with a healthy lung the diaphragm restores its normal curvature, thus decreasing the abdominal distension.

OEP has been used to reveal post-operative ventilatory asymmetries. De Groote et al. [97] analyzed how 2 lungs with different mechanical properties may influence CW dynamics. Imbalances in the extent and rate of inflation or deflation between native and transplanted lung could be explained by different changes in the volume of the 2 hemithoraxes (due to hyperinflation of the native lung), by displacement of the mediastinum, or by a combination of both. Changes in the volume of each hemithorax were measured by OEP during $\mathrm{CO}_{2}$-induced hyperpnoea and forced expiration in male patients who had undergone single LT for emphysema [97]. The authors reported similar volumes of the 2 hemithoraxes at both functional residual capacity and total lung capacity, thus showing that the unequal volumes of the native lung and the graft are accommodated by displacement of the mediastinum rather than by volume distortion. 
Table 2. Studies utilizing OEP in the evaluation of patients with neuromuscular diseases

\begin{tabular}{|c|c|c|c|}
\hline First author [Ref.], year & Pathology, sample characteristics & Aim & Findings \\
\hline Lo Mauro [26], 2010 & $\begin{array}{l}\text { DMD patients at different stages of } \\
\text { the disease, } n=66\end{array}$ & $\begin{array}{l}\text { To investigate if } \mathrm{V}_{\mathrm{AB}} \text { contribution to } \\
\mathrm{V}_{\mathrm{T}} \text { should be considered an early } \\
\text { indicator of respiratory impairment in } \\
\text { DMD }\end{array}$ & $\begin{array}{l}\text { In the supine position, the average contribution } \\
\text { of } V_{A B} \text { to } V_{T} \text { progressively decreased with age } \\
\mathrm{NH} \text { patients showed significantly lower } \\
\text { contribution of VAB changes }\end{array}$ \\
\hline Romei 118], 2012 & DMD, $n=40$ & $\begin{array}{l}\text { To determine if } \mathrm{V}_{\mathrm{RC}} \text { and } \mathrm{V}_{\mathrm{AB}} \text { can be } \\
\text { helpful to distinguish those patients } \\
\text { who are in the early stages of } \mathrm{NH} \\
\text { development from those who are not } \\
\text { yet }\end{array}$ & $\begin{array}{l}\text { In supine position during the slow VC } \\
\text { manoeuvre, ventilator parameters are } \\
\text { significantly lower in DMD patients } \\
\text { In seated position, DMD patients showed lower } \\
\text { MV than healthy subjects during quiet } \\
\text { breathing }\end{array}$ \\
\hline D’Angelo [119], 2011 & $\begin{array}{l}\text { DMD patients ( } 4 \text { groups according } \\
\text { to age), } n=114\end{array}$ & $\begin{array}{l}\text { To identify early markers of } \\
\text { respiratory insufficiency and rule out } \\
\text { the role of pharmacological and } \\
\text { surgical therapies in DMD }\end{array}$ & $\begin{array}{l}\text { A subgroup of adolescent DMD patients } \\
\text { showed differences in } \mathrm{AB} \text { contribution to } \mathrm{V}_{\mathrm{CW}} \\
\text { related to the time spent with low oxygen } \\
\text { saturation during night, despite similar } \\
\text { spirometric parameters } \\
\text { The inadequate pre-inspiration and insufficient } \\
\text { expiratory flow, particularly of the RC muscles } \\
\text { seemed to be the cause underlying the } \\
\text { progressive inefficient cough typical of the } \\
\text { natural course of the disease }\end{array}$ \\
\hline Bonato [120], 2011 & DMD patients, $n=40$ & $\begin{array}{l}\text { To investigate the relation between } \\
\text { the reduction of VC and inspiratory } \\
\text { muscle weakness and the ability to } \\
\text { breathe autonomously }\end{array}$ & $\begin{array}{l}\text { Relationship between the } \mathrm{CW} \text { variations and } \\
\text { the saturations showed differences in } \mathrm{AB} \\
\text { contribution to } \mathrm{V}_{\mathrm{CW}} \text { variations related to the } \\
\text { time spent with low oxygen saturation during } \\
\text { night, despite similar spirometric parameters }\end{array}$ \\
\hline $\begin{array}{l}\text { Lo Mauro [91], } 2014 \\
\text { Lo Mauro [92], } 2012\end{array}$ & $\begin{array}{l}\text { DMD patients, } n=36 \\
\text { ( } 3 \text { groups according to the peak } \\
\text { cough flow) }\end{array}$ & $\begin{array}{l}\text { To investigate if thoraco-abdominal } \\
\text { operating volumes during coughing } \\
\text { determine the effectiveness of cough } \\
\text { in DMD patients }\end{array}$ & $\begin{array}{l}\text { During the inspiration preceding cough, } \\
\text { patients with efficient cough showed normal } \\
\text { volume variations whereas patients with } \\
\text { intermediate cough efficiency showed low } \mathrm{AB} \\
\text { volume variation } \\
\text { Patients with inefficient cough were } \\
\text { characterized by reduced total and } \\
\text { compartmental CW volumes during the } \\
\text { inspiration preceding cough and reduced } \mathrm{AB} \\
\text { contribution to } \mathrm{V}_{\mathrm{T}} \text { during quiet breathing }\end{array}$ \\
\hline D’Angelo [90], 2012 & $\begin{array}{l}\text { DMD, } n=45: 15 \text { with spinal } \\
\text { fusion, } 22 \text { with severe scoliosis } \\
\left(\text { Cobb angle }>20^{\circ}\right), 8 \text { with mild } \\
\left.\text { scoliosis (Cobb angle }<20^{\circ}\right)\end{array}$ & $\begin{array}{l}\text { To compare the rate of decline in } \\
\text { respiratory function in } 3 \text { groups of } \\
\text { non-ambulant DMD patients, divided } \\
\text { according to Cobb angle and spinal } \\
\text { fusion }\end{array}$ & $\begin{array}{l}\text { The decline of } \mathrm{V}_{\mathrm{AB}} \text { contribution to the } \mathrm{CW} \text { in } \\
\text { the } \mathrm{DMD} \text { patients who underwent spinal fusion } \\
\text { is far less evident and steep than the one } \\
\text { indicated by the FVC, and it occurs in a longer } \\
\text { period of time }\end{array}$ \\
\hline Lanini [89], 2008 & $\begin{array}{l}\text { BMD, } n=3 \\
\text { FSHD, } n=1 \\
\text { LGMD, } n=2 \\
\text { Myotonic dystrophy, } n=2 \\
\text { Healthy subjects, } n=12\end{array}$ & $\begin{array}{l}\text { To test the hypothesis that operating } \\
\text { forces on the CW may impact on } \\
\text { distribution of inspired gas volume to } \\
\mathrm{RC} \text { compartments, resulting in RC } \\
\text { distortion and decrease in cough } \\
\text { effectiveness }\end{array}$ & $\begin{array}{l}\text { The cough peak flow was negatively correlated } \\
\text { with the distortion of the CW, but not with } \\
\text { respiratory muscle strength }\end{array}$ \\
\hline D’Angelo [119], 2011 & $\begin{array}{l}\text { LGMD, } n=38 \\
\text { BMD, } n=20 \\
\text { FSHD, } n=30 \\
\text { Healthy subjects, } n=20\end{array}$ & $\begin{array}{l}\text { To study the CW behaviour in a large } \\
\text { population of patients affected with } \\
\text { LGMD, BMD, and FSHD }\end{array}$ & $\begin{array}{l}\text { Both IC and VC were significantly lower in } \\
\text { LGMD and FSHD patients than in healthy } \\
\text { subjects } \\
\text { BMD patients showed slightly lower values of } \\
\text { IC and normal values of VC } \\
\text { AB contribution was reduced in wheelchair- } \\
\text { bound patients with LGMD and FSHD in the } \\
\text { seated position }\end{array}$ \\
\hline Bourdarham [25], 2013 & $\begin{array}{l}\text { Myotonic dystrophy, } n=6 \\
\text { Acid maltase deficiency, } n=5 \\
\text { Mitochondrial myopathy, } n=1 \\
\text { DMD, } n=1 \\
\text { Spinal muscular atrophy, } n=1 \\
\text { Neuralgic amyotrophy, } n=6\end{array}$ & $\begin{array}{l}\text { To determine whether OEP accurately } \\
\text { evaluated VC in patients with } \\
\text { respiratory muscle dysfunction of } \\
\text { variable severity, including those with } \\
\text { paradoxical AB movements }\end{array}$ & $\begin{array}{l}\text { In subjects with various degrees of restrictive } \\
\text { respiratory disease, VC evaluated with } \\
\text { spirometry and OEP showed a strong positive } \\
\text { correlation and relatively good agreement }\end{array}$ \\
\hline
\end{tabular}


Table 2 (continued)

\begin{tabular}{llll}
\hline First author [Ref.], year & Pathology, sample characteristics & Aim & Findings \\
\hline Lo Mauro [27], 2014 & $\begin{array}{l}\text { SMA, } n=18 \\
\text { Healthy subjects, } n=18\end{array}$ & $\begin{array}{l}\text { To study how CW kinematics and } \\
\text { respiratory muscles change in relation } \\
\text { to SMA severity }\end{array}$ & $\begin{array}{l}\text { In mild SMA and intermediate SMA, RC } \\
\text { motion was significantly reduced and } \\
\text { sometimes paradoxical during quiet breathing } \\
\text { in the supine position }\end{array}$ \\
\hline Lissoni [93], 1998 & $\begin{array}{l}\text { SMA type II, } n=9 \\
\text { Healthy subjects, } n=13\end{array}$ & $\begin{array}{l}\text { To analyse CW kinematics during } \\
\text { spontaneous breathing (healthy } \\
\text { subjects) and during spontaneous } \\
\text { breathing and while using } \\
\text { mechanically assisted ventilation } \\
\text { (SMA patients) }\end{array}$ & $\begin{array}{l}\text { CW kinematic analysis may be helpful for } \\
\text { choosing the ventilation parameters to optimize } \\
\text { therapeutic benefits }\end{array}$ \\
& & $\begin{array}{l}\text { To analyse thoraco-abdominal } \\
\text { volume changes when breathing } \\
\text { spontaneously and when breathing } \\
\text { deeply }\end{array}$ & $\begin{array}{l}\text { Kinematic analysis can be helpful in } \\
\text { determining differences in regional lung } \\
\text { mobility and risk for nocturnal ventilatory } \\
\text { dysfunction in children with SMA }\end{array}$ \\
\hline Lissoni [124], 1996 & SMA, $n=12$ & Healthy subjects, $n=13$ &
\end{tabular}

DMD, Duchenne muscular distrophy; NH, nocturnal hypoxemia; MV, minute volume; BMD, Becker's muscular dystrophy; FSHD, facioscapulohumeral dystrophy; LGMD, limb-girdle dystrophy myotonic; SMA, spinal muscular atrophy.

A widespread application of OEP is in tailoring postoperative PR. Several studies have pointed out the efficacy of PR for COPD patients, but less evidence exists for surgical conditions. In Bastianini et al. [54], patients receiving superior lobectomy for non-small cell lung cancer underwent CW kinematic assessment before and immediately after surgery, as well as after 2 weeks of PR. FEV 1 and FVC were found to be decreased between the presurgery (PreS) phase and the post-surgery phase (PostS) and partially recovered after rehabilitation (PostR). Notably, the authors reported a significant negative correlation between $\mathrm{FEV}_{1}$ measured during PreS and the $\mathrm{FEV}_{1}$ decreasing from PreS to PostR. The above-mentioned findings agree with the results of Cesario et al. [98], although a lower improvement in the latter study was observed after 4-week PR. In another study aimed at testing an OEP system as a diagnostic tool to assess the efficacy of asymmetric PR, Bastianini et al. [99] assessed $V_{T}$ variations of the 6 compartments (the left and right sides of $\mathrm{RCp}, \mathrm{RCa}$, and $\mathrm{AB}$ ) in patients who had undergone left or right superior lobectomy, in PreS, PostS, and PostR phases. Even though PR did not improve the overall volumes, the VT of the non-operated side increased between PreS and PostR. This indicates that PR was more effective on the non-operated side, which then compensates the contralateral one. The negative effect of $\mathrm{CW}$ tumours on global CW mechanics during quiet breathing and exercise has been confirmed by Elshafie et al. [100] in a recent study on a patient with unilateral extra-thoracic CW sarcoma. They demonstrated that surgery reverses this abnormality, but only at rest.

\section{Evaluation of Other Health Conditions}

OEP has been used in several clinical applications to study different pathological conditions. Due to the large number of studies in each category, the main scientific findings are summarized in Table 3 , and only the main applications are briefly described in this section.

OEP has been used to study thorax and CW deformity, in children with pectus excavatum $[101,102]$ with osteogenesis imperfecta type III and type IV (connective tissue disorder characterized by bone fragility, multiple fractures, and significant CW deformities) [107], and in adults with ankylosing spondylitis [103, 104], and to evaluate the effect of posture on breathing kinematics in subjects with spinal cord injury [55]. OEP has also been used to investigate $\mathrm{V}_{\mathrm{T}}$ differences between paretic and healthy sides during quiet breathing, voluntary hyperventilation, and hypercapnic stimulation in post-stroke patients with hemiparesis [21]. One study analyzed the ventilator breathing pattern in patients with late-onset glycogen storage disease type II. This is an autosomal recessive lysosomal storage disease due to glucosidase alpha acid deficiency, a slowly progressive disease predominantly affecting skeletal and respiratory muscles [105]. Frazão et al. [106] used the OEP to assess the outcome of a respiratory rehabilitative treatment using PEP-Mask in Parkinson disease patients.

In patients with chronic heart failure plus cardiomegaly, significant differences in the regional distribution of $\mathrm{RC}$ volumes were found among patients with heart failure associated with cardiomegaly and healthy controls [107]. 
Table 3. Studies utilizing OEP in the evaluation of other pathological conditions

\begin{tabular}{|c|c|c|}
\hline First author [Ref.], year & $\begin{array}{l}\text { Pathology, sample } \\
\text { characteristics }\end{array}$ & Findings \\
\hline $\begin{array}{l}\text { Binazzi [101], } 2012 \\
\text { Redlinger [102], } 2011\end{array}$ & $\begin{array}{l}\text { Pectus excavatum, } n=24 \\
n=119\end{array}$ & $\begin{array}{l}\text { The } V_{C W}, V_{R C p}, V_{R C a} \text {, and } V_{A B} \text { at rest are similar in patients with } P E \\
\text { and in healthy subjects } \\
\text { During maximal respiration, } \mathrm{PE} \text { patients had a significant increase in } \\
\text { the volume within the RCa compared with healthy ones } \\
\text { Patients with PE demonstrated significantly decreased midline marker } \\
\text { excursion at the level of the pectus defect }\end{array}$ \\
\hline Lo Mauro [40], 2012 & $\begin{array}{l}\text { Osteogenesis imperfecta type } \\
\text { III and IV, } n=22\end{array}$ & $\begin{array}{l}\text { Pectus carinatum characterizes osteogenesis imperfecta type III } \\
\text { patients and alters respiratory muscle coordination, leading to CW } \\
\text { and RC distortions and an inefficient ventilator pattern }\end{array}$ \\
\hline $\begin{array}{l}\text { Ferrigno [103], } 1998 \\
\text { Romagnoli [104], } 2004\end{array}$ & $\begin{array}{l}\text { Ankylosing spondylitis, } \\
n=17, n=6\end{array}$ & $\begin{array}{l}\text { During rebreathing, CW expansion increased (AB component } \\
\text { increased more) to a similar extent in patients with ankylosing } \\
\text { spondylitis to that of unhealthy subjects } \\
\text { RC inspiratory peak and muscle pressure was significantly lower in } \\
\text { patients than in controls subjects, but not the AB }\end{array}$ \\
\hline Boudarham [121], 2013 & $\begin{array}{l}\text { Unilateral diaphragm } \\
\text { weakness, } n=13\end{array}$ & $\begin{array}{l}\text { OEP detected asymmetric ventilation in all patients diagnosed with } \\
\text { unilateral diaphragm weakness and in no patients without this } \\
\text { diagnosis } \\
\text { OEP is an effective non-invasive alternative that is preferred by the } \\
\text { patients over diaphragm compound muscle action potential response } \\
\text { and lateral twitch transdiaphragmatic pressure }\end{array}$ \\
\hline Meric [122], 2016 & $\begin{array}{l}\text { Late-onset Pompe disease, } \\
n=11\end{array}$ & $\begin{array}{l}\mathrm{AB} \text { contribution and } \mathrm{V}_{\mathrm{AB}} \text { during the } \mathrm{VC} \text { manoeuvre are reliable and } \\
\text { non-invasive indices of diaphragmatic function in Pompe disease }\end{array}$ \\
\hline Remiche [105], 2013 & $\begin{array}{l}\text { Late-onset glycogen storage } \\
\text { disease type II, } n=10\end{array}$ & $\begin{array}{l}\text { Higher MV in the supine position were found in patients with } \\
\text { diaphragmatic weakness (supine FVC fall higher than 25\%) compared } \\
\text { with patients without diaphragmatic weakness (supine FVC change } \\
\leq 25 \% \text { ) } \\
\text { In the seating and in the supine position, patients were characterized } \\
\text { by reduced CW IC and by a poor ability to mobilize the AB, both AB } \\
\text { IC and AB ERV being significantly lower than in control subjects }\end{array}$ \\
\hline Lanini [21], 2003 & $\begin{array}{l}\text { Hemiplegia due to a } \\
\text { cerebrovascular accident, } \\
n=8\end{array}$ & $\begin{array}{l}\mathrm{V}_{\mathrm{T}} \text { of paretic and healthy sides were similar during quiet breathing } \\
\text { Hemiparetic stroke produced asymmetric ventilation with an increase } \\
\text { in carbon dioxide sensitivity and a decrease in voluntary ventilation } \\
\text { on the paretic side }\end{array}$ \\
\hline Frazão [106], 2014 & $\begin{array}{l}\text { Parkinson disease patients, } \\
n=15\end{array}$ & $\begin{array}{l}\text { The study did not find significant difference in } \mathrm{AB} \text { compartment } \\
\text { contribution between Parkinson disease patients and healthy subjects } \\
\text { during quiet breathing even with Parkinson disease patients showing } \\
\text { higher } \mathrm{V}_{\mathrm{T}} \text { values }\end{array}$ \\
\hline Brandão [107], 2012 & $\begin{array}{l}\text { Chronic heart failure plus } \\
\text { cardiomegaly patients, } \\
n=19\end{array}$ & $\begin{array}{l}\text { Left side of the } \mathrm{RCa} \text { is characterized by lower displacement during } \\
\text { inspiratory loaded breathing } \\
\text { Regional distribution differences in } \mathrm{V}_{\mathrm{CW}} \text { are correlated with other } \\
\text { functional parameters, namely left ventricular ejection fraction and } \\
\text { dyspnoea }\end{array}$ \\
\hline
\end{tabular}

VC, vital capacity; MV, minute volume; FVC, functional ventilatory capacity; IC, inspiratory capacity; ERV, expiratory reserve volume.

OEP in Clinical Practice and Research 
Table 4. Studies that used OEP to evaluate chest wall movement and breathing pattern during exercise

\begin{tabular}{|c|c|c|c|}
\hline $\begin{array}{l}\text { First author [Ref.], } \\
\text { year }\end{array}$ & Sample characteristics & Aims & Findings \\
\hline Vogiatzis [123], 2005 & $\begin{array}{l}n=15 \text { (10 males, } \\
5 \text { females })\end{array}$ & $\begin{array}{l}\text { To investigate the pattern of response } \\
\text { in operational lung volumes and } \\
\text { relative contribution of respiratory } \\
\text { muscle groups between men and } \\
\text { women of similar fitness }\end{array}$ & $\begin{array}{l}\text { Men exhibited significantly greater } \\
\text { operational lung volumes than women } \\
\text { during symptom-limited exercise } \\
\text { During the incremental exercise, } \mathrm{EIV}_{\mathrm{CW}} \text { is } \\
\text { progressively increased and } \mathrm{EEV}_{\mathrm{CW}} \text { is } \\
\text { decreased, and both genders utilised } \\
\text { primarily the muscles of the rib cage } \\
\text { compartment rather than those of the } \\
\text { abdomen }\end{array}$ \\
\hline Layton [112], 2011 & $\begin{array}{l}n=18 \text { ET } \\
(11 \text { males, } 7 \text { females }) \\
n=14 \text { UT } \\
\text { (9 males, } 5 \text { females })\end{array}$ & $\begin{array}{l}\text { To determine how increased } \\
\text { ventilatory demand impacts } \\
\text { ventilatory kinematics and if there is } \\
\text { any difference in the total chest wall } \\
\text { volume variations ( } \mathrm{V}_{\mathrm{CW}} \text { ) of male and } \\
\text { female endurance-trained athletes } \\
\text { (ET) compared to untrained } \\
\text { individuals (UT) during exercise }\end{array}$ & $\begin{array}{l}\text { With peak exercise, female ET did not } \\
\text { change } E E V_{C W} \text { or } E E V_{R C p} \text {, while female } U T \\
\text { significantly decreased both parameters } \\
\text { ET had significant increases in EIV } V_{R C p} \text {, while } \\
\text { UT did not } \\
\text { Women demonstrated lower contribution of } \\
\text { the } V_{A B} \text { and greater contribution of } V_{R C p} \\
\text { when compared to men } \\
\text { Men demonstrated similar contribution of } \\
\text { the } V_{R C p} \text { and the } V_{A B}\end{array}$ \\
\hline Layton [113], 2013 & $\begin{array}{l}n=16 \mathrm{ET} \\
n=14 \mathrm{UT}\end{array}$ & $\begin{array}{l}\text { To compare measurements of } \mathrm{V}_{\mathrm{T}} \text { by } \\
\text { OEP and spirometry during a } \\
\text { maximal cycling exercise test }\end{array}$ & $\begin{array}{l}\text { Discrepancy of }-2.4 \pm 3.9 \% \text { between the } 2 \\
\text { methods during maximal exercise and } \\
-2.0 \pm 7.2 \% \text { during submaximal exercise }\end{array}$ \\
\hline
\end{tabular}

FVC, functional vital capacity; $\mathrm{EIV}_{\mathrm{CW}}$, end-inspiratory chest wall volume; $\mathrm{EEV}_{\mathrm{CW}}$, end-expiratory chest wall volume; $\mathrm{V}_{\mathrm{CW}}$, total chest wall volume variations; $\mathrm{EEV}_{\mathrm{RCp}}$, end-expiratory pulmonary rib cage volume; $\mathrm{EIV}_{\mathrm{RC}}$, end-inspiratory pulmonary rib cage volume; $\mathrm{V}_{\mathrm{AB}}$, abdominal volume; ET, endurance-trained athletes; UT, untrained athletes.

Barcelar et al. [70] demonstrated, with the use of the OEP, in obese women (BMI $>40$ ), that not only lung but also $\mathrm{CW}$ function is altered.

\section{OEP in Exercise Science}

The function of the respiratory system during exercise is usually assessed by the analysis of expired air to calculate breathing frequency, $\mathrm{V}_{\mathrm{T}}$, minute ventilation, oxygen consumption, and carbon dioxide production. These methods are commonly used and are valuable in the quantification of fitness status and diagnosis of a range of cardiovascular and respiratory diseases [108].

Until recently, the movement of the chest and $A B$ during exercise has not been considered in either the understanding of optimal breathing pattern nor in relation to exercise respiratory diseases. The assessment of chest and $\mathrm{AB}$ wall movement during exercise may also assist in the understanding of breathing pattern disorders and exercise-triggered dysfunctional breathing [109].
Dickinson et al. [110] have previously reported that using breathing technique and inspiratory muscle training has been successful in eliminating exercise respiratory symptoms during high-intensity exercise in an elite athlete; however, the absence of a method to track chest and $\mathrm{AB}$ wall movements meant it was impossible to quantify any changes in breathing mechanics.

Investigations into the use of OEP to assess the movement of the chest and $\mathrm{AB}$ during exercise are emerging. Initial reports suggest EIV increases during exercise are mainly achieved by increasing end-inspiratory volumes of the RCp and RCa reflecting the inspiratory RC muscle contribution [111]. Initial work from Layton et al. [112, 113] using OEP suggests that during exercise females have less contribution from $V_{A B}$ and greater contribution of $\mathrm{V}_{\mathrm{RCp}}$ when compared to males. Table 4 provides an overview of the studies that have used OEP to evaluate the breathing pattern and CW movement during exercise.

Further investigations using OEP during exercise will assist our understanding of the relationship between respiratory and locomotor muscle fatigue, posture, and 
$\mathrm{CW}$ movement. These types of investigations can then aid the delivery of specific therapy and breathing training programmes targeted towards reducing exercise respiratory symptoms and optimizing chest and $\mathrm{AB}$ wall movement during exercise.

\section{Conclusions}

OEP is an innovative non-invasive tool for measuring different compartments of the $\mathrm{CW}$ and thus lung volume variations. OEP has been shown to be a valuable and accurate assessment tool that can provide crucial information about $\mathrm{CW}$ mechanics across the respiratory field.

The high accuracy and validity of the OEP to measure volume variations assessed in different populations and experimental protocols allow to successfully use this tool in newborns, children, and healthy and pathological subjects; OEP allows the study of both breathing volumes and biomechanical indexes for a better comprehension of the work of breathing without interferences using invasive instrumentation.

Despite the fact that OEP has been used in research, the large number of markers strongly discourage its employment in the daily clinical practice as an alternative tool for traditional flow-based instrument to assess respi- ratory parameters. In fact, the marker placement can be tedious and complicated, especially in subjects in which the landmarks are difficult to identify. Marker placement is also time-consuming and therefore requires dedicated staff. In order to make OEP more practical for an applied patient setting, future investigations should focus on reducing the marker set or integrate OEP into wearable technology.

Moreover, at the moment, the cost of an 8-camera OEP system is very high; however, computer programs to compute breathing volumes from markers have recently been described in the literature, and they will be profitably used with all high-resolution commercial motion capture systems.

OEP may be used in the future to assist in the understanding of breathing patterns in respiratory conditions that are difficult to diagnose objectively, e.g. dysfunctional breathing, and therefore it may have the potential to contribute to an improvement in therapeutic strategies.

\section{Acknowledgement}

This work was supported by the Italian MIUR PRIN 2012 Project (Prot. 20127XJX57, P.I. Paolo Cappa).

\section{References}

1 Milhorn HT, Benton R, Ross R, Guyton AC: A mathematical model of the human respiratory control system. Biophys J 1965;5:27-46.

2 Otis AB, Fenn WO, Rahn H: Mechanics of breathing in man. J Appl Physiol 1950;2:592607.

3 Goldman MD, Grimby G, Mead J: Mechanical work of breathing derived from rib cage and abdominal V-P partitioning. J Appl Physiol 1976;41:752-763.

4 Hoppin FJ, Stothert JJ, Greaves I, Lai Y-L, Hildebrandt J: Lung recoil: elastic and rheological properties; in Macklem PT, Mead J (eds): Handbook of Physiology. The Respiratory System. Mechanics of Breathing. Bethesda, American Physiological Society, section 3, vol III, part 1, 1986, pp 195-215.

5 Bayliss LE, Robertson GW: The visco-elastic properties of the lungs. Q J Exp Physiol Cogn Med Sci 1939;29:27-47.

6 Peslin R, Papon J, Duviver C, Richalet J: Frequency response of the chest: modeling and parameter estimation. J Appl Physiol 1975;39: 523-534.

OEP in Clinical Practice and Research
7 Konno K, Mead J: Measurement of the separate volume changes of rib cage and abdomen during breathing. J Appl Physiol 1967;22: 407-422.

8 Mead J: The control of respiratory frequency. Ann NY Acad Sci 1963;109:724-729.

9 Mead J, Peterson N, Grimby G, Mead J: Pulmonary ventilation measured from body surface movements. Science 1967;156:13831384.

10 Barnas GM, Yoshino K, Stamenovic D, Kikuchi Y, Loring SH, Mead J: Chest wall impedance partitioned into rib cage and diaphragmabdominal pathways. J Appl Physiol 1989;66: 350-359.

11 Barnas GM, Yoshino K, Loring SH, Mead J: Impedance and relative displacements of relaxed chest wall up to $4 \mathrm{~Hz}$. J Appl Physiol 1987;62:71-81.

12 Peslin R, Duvivier C, Gallina C: Total respiratory input and transfer impedances in humans. J Appl Physiol 1985;59:492-501.

13 Ferrigno G, Pedotti A: ELITE: a digital dedicated hardware system for movement analysis via real-time TV signal processing. IEEE Trans Biomed Eng 1985;32:943-950.
14 Cala SJ, Kenyon CM, Ferrigno G, Carnevali P, Aliverti A, Pedotti A, et al: Chest wall and lung volume estimation by optical reflectance motion analysis. J Appl Physiol 1996;81:26802689.

15 Ferrigno G, Carnevali P, Aliverti A, Molteni F, Beulcke G, Pedotti A: Three-dimensional optical analysis of chest wall motion. J Appl Physiol 1994;77:1224-1231.

16 Aliverti A, Dellacà R, Pelosi P, Chiumello D, Gattinoni L, Pedotti A: Compartmental analysis of breathing in the supine and prone positions by optoelectronic plethysmography. Ann Biomed Eng 2001;29:60-70.

17 Iandelli I, Rosi E, Scano G: The ELITE system; in Monaldi Archives for Chest Disease. Naples, Second University of Naples, 1999, pp 498-501.

18 Massaroni C, Schena E, Bastianini F, Scorza A, Saccomandi P, Lupi G, et al: Development of a bio-inspired mechatronic chest wall simulator for evaluating the performances of opto-electronic plethysmography. Open Biomed Eng J 2014;8:120-130. 
19 Lanini B, Bianchi R, Binazzi B, Romagnoli I, Pala F, Gigliotti F, et al: Chest wall kinematics during cough in healthy subjects. Acta Physiol 2007;190:351-358.

20 Vogiatzis I, Athanasopoulos D, Boushel R, Guenette JA, Koskolou M, Vasilopoulou M, et al: Contribution of respiratory muscle blood flow to exercise-induced diaphragmatic fatigue in trained cyclists. J Physiol 2008;586: 5575-5587.

21 Lanini B, Bianchi R, Romagnoli I, Coli C, Binazzi B, Gigliotti F, et al: Chest wall kinematics in patients with hemiplegia. Am J Respir Crit Care Med 2003;168:109-113.

22 Hostettler S, Illi SK, Mohler E, Aliverti A, Spengler CM: Chest wall volume changes during inspiratory loaded breathing. Respir Physiol Neurobiol 2011;175:130-139.

23 Gorini M, Iandelli I, Misuri G, Bertoli F, Filippelli M, Mancini M, et al: Chest wall hyperinflation during acute bronchoconstriction in asthma. Am J Respir Crit Care Med 1999;160: 808-816.

24 BTS Bioengineering: Optoelectronic Plethysmography Compendium Marker Setup; A Handbook about Marker Positioning on Subjects in Standing and Supine Positions. Brooklyn, BTS Bioengineering, 2011.

25 Boudarham J, Pradon D, Prigent H, Vaugier I, Barbot F, Letilly N, et al: Optoelectronic vital capacity measurement for restrictive diseases. Respir Care 2013;58:633-638.

26 Lo Mauro A, D’Angelo MG, Romei M, Motta F, Colombo D, Comi GP, et al: Abdominal volume contribution to tidal volume as an early indicator of respiratory impairment in Duchenne muscular dystrophy. Eur Respir J 2010;35:1118-1125.

27 Lo Mauro A, Romei M, Priori R, Laviola M, D’Angelo MG, Aliverti A: Alterations of thoraco-abdominal volumes and asynchronies in patients with spinal muscle atrophy type III. Respir Physiol Neurobiol 2014;197:1-8.

28 Dellaca RRL, Ventura MML, Zannin EA, Natile M, Pedotti A, Tagliabue P: Measurement of total and compartmental lung volume changes in newborns by optoelectronic plethysmography. Pediatr Res 2010;67:11-16.

29 Aliverti A, Dellacà R, Pelosi $\mathrm{P}$, Chiumello $\mathrm{D}$, Pedotti A, Gattinoni L: Optoelectronic plethysmography in intensive care patients. Am J Respir Crit Care Med 2000;161:1546-1552.

30 Reinaux CMA, Aliverti A, da Silva LGM, da Silva RJ, Gonçalves JN, Noronha JB, et al: Tidal volume measurements in infants: optoelectronic plethysmography versus pneumotachograph. Pediatr Pulmonol 2016;51:850857.

31 Binazzi B, Lanini B, Bianchi R, Romagnoli I, Nerini M, Gigliotti F, et al: Breathing pattern and kinematics in normal subjects during speech, singing and loud whispering. Acta Physiol (Oxf) 2006;186:233-246.
32 Dellacà RL, Black LD, Atileh H, Pedotti A, Lutchen KR: Effects of posture and bronchoconstriction on low-frequency input and transfer impedances in humans. J Appl Physiol 2004;97:109-118.

33 Filippelli M, Duranti R, Gigliotti F, Bianchi R, Grazzini M, Stendardi L, et al: Overall contribution of chest wall hyperinflation to breathlessness in asthma. Chest 2003;124:21642170.

34 Laviola M, Zanini A, Priori R, Macchini F, Leva E, Torricelli M, et al: Thoraco-abdominal asymmetry and asynchrony in congenital diaphragmatic hernia. Pediatr Pulmonol DOI: $10.1002 /$ ppul.23081.

35 Aliverti A, Dellacà RL, Lotti P, Bertini S, Duranti R, Scano G, et al: Influence of expiratory flow-limitation during exercise on systemic oxygen delivery in humans. Eur J Appl Physiol 2005;95:229-242.

36 Allard P, Blanchi JP, Aissaoui R: Bases of three-dimensional reconstruction; in Allard $\mathrm{P}$, Stokes IAF, Blanchi JP (eds): Three-Dimensional Analysis of Human Movement. Champaign, Human Kinetics, 1995, pp 1940.

37 Andrews JG: Euler's and Lagrange's equations for linked rigid-body models of threedimensional human motion; in Allard P, Stokes IAF Blanchi JP (eds): Three-Dimensional Analysis of Human Movement. Champaign, Human Kinetics, 1995, pp 145-175.

38 Aliverti A, Pedotti A: Opto-electronic plethysmography. Monaldi Arch Chest Dis - Pulm Ser 2003;59:12-16.

39 Romagnoli I, Lanini B, Binazzi B, Bianchi R, Coli C, Stendardi L, et al: Optoelectronic plethysmography has improved our knowledge of respiratory physiology and pathophysiology. Sensors 2008;8:7951-7972.

40 Lo Mauro A, Pochintesta S, Romei M, D’angelo MG, Pedotti A, Turconi AC, et al: Rib cage deformities alter respiratory muscle action and chest wall function in patients with severe osteogenesis imperfecta. PLoS One 2012; 7:e35965.

41 Papa GFS, Pellegrino GM, Di Marco F, Imeri G, Brochard L, Goligher E, et al: A review of the ultrasound assessment of diaphragmatic function in clinical practice. Respiration 2016;91:403-411.

42 Sackner MA, Gonzalez H, Rodriguez M, Belsito A, Sackner DR, Grenvik S: Assessment of asynchronous and paradoxic motion between rib cage and abdomen in normal subjects and in patients with chronic obstructive pulmonary disease. Am Rev Respir Dis 1984;130: 588-593.

43 Tobin MJ, Chadha TS, Jenouri G, Birch SJ, Gazeroglu HB, Sackner MA: Breathing patterns. 1. Normal subjects. Chest 1983;84:202205.

44 Allen JL, Wolfson MR, McDowell K, Shaffer $\mathrm{TH}$ : Thoracoabdominal asynchrony in infants with airflow obstruction. Am Rev Respir Dis 1990;141:337-342.
45 Kiciman NM, Andréasson B, Bernstein G, Mannino FL, Rich W, Henderson C, et al: Thoracoabdominal motion in newborns during ventilation delivered by endotracheal tube or nasal prongs. Pediatr Pulmonol 1998;25: 175-181.

46 Mayer OH, Clayton RG, Jawad AF, McDonough JM, Allen JL: Respiratory inductance plethysmography in healthy 3- to 5year-old children. Chest 2003;124:18121819.

47 Agostoni E, Mognoni P: Deformation of the chest wall during breathing efforts. J Appl Physiol 1966;21:1827-1832.

48 Beydon N, Davis SD, Lombardi E, Allen JL, Arets HGM, Aurora P, et al: An Official American Thoracic Society/European Respiratory Society Statement: Pulmonary function testing in preschool children. Am J Respir Crit Care Med 2007;175:1304-1345.

49 Millard RK: Inductive plethysmography components analysis and improved non-invasive postoperative apnoea monitoring. Physiol Meas 1999;20:175-186.

50 Parreira VF, Vieira DSR, Myrrha MAC, Pessoa IMBS, Lage SM, Britto RR: Optoelectronic plethysmography: a review of the literature. Rev Bras Fisioter 2012;16:439-453.

51 Tantucci C, Bottone D, Borghesi A, Guerini M, Quadri F, Pini L: Methods for measuring lung volumes: is there a better one? Respiration 2016;91:273-280.

52 Aliverti a, Stevenson N, Dellacà RL, et al: Regional chest wall volumes during exercise in chronic obstructive pulmonary disease. Tho$\operatorname{rax} 2004 ; 59: 210-216$.

53 Georgiadou O, Vogiatzis I, Stratakos G, Koutsoukou A, Golemati S, Aliverti A, et al: Effects of rehabilitation on chest wall volume regulation during exercise in COPD patients. Eur Respir J 2007;29:284-291.

54 Bastianini F, Silvestri S, Schena E, Cecchini S, Sterzi S: Evaluation of pulmonary rehabilitation after lung resection through opto-electronic plethysmography. Conf Proc IEEE Eng Med Biol Soc 2010;2010:2481-2484.

55 Miccinilli S, Morrone M, Bastianini F, Molinari M, Scivoletto G, Silvestri S, et al: Optoelectronic plethysmography to evaluate the effect of posture on breathing kinematics in spinal cord injury: a cross sectional study. Eur J Phys Rehabil Med 2016;52:36-47.

56 Duranti R, Filippelli M, Bianchi R, Romagnoli I, Pellegrino R, Brusasco V, et al: Inspiratory capacity and decrease in lung hyperinflation with albuterol in COPD. Chest 2002;122: 2009-2014.

57 Bastianini F, Schena E, Silvestri S: Accuracy evaluation on linear measurement through opto-electronic plethysmograph. Conf Proc IEEE Eng Med Biol Soc 2012;2012:1-4. 
58 Bastianini F, Schena E, Saccomandi P, Silvestri S: Accuracy evaluation of dynamic volume measurements performed by opto-electronic plethysmograph, by using a pulmonary simulator. Conf Proc IEEE Eng Med Biol Soc 2013; 2013:930-933.

59 Massaroni C, Schena E, Saccomandi P, Silvestri S: Motion capture systems for breathing analysis : calibration procedure and experimental trials by the use of a novel in-situ tool for volumetric calibration. Conf Proc IEEE Eng Med Biol Soc 2016;2016:5797-5800.

60 Schena E, Massaroni C, Saccomandi P, Cecchini S: Flow measurement in mechanical ventilation: a review. Med Eng Phys 2015;37: 257-264.

61 Aliverti A, Dellacà R, Pelosi $\mathrm{P}$, Chiumello D, Gattinoni L, Pedotti A: Compartmental analysis of breathing in the supine and prone positions by optoelectronic plethysmography. Ann Biomed Eng 2001;29:60-70.

62 Vieira DSR, Hoffman M, Pereira DAG, Britto RR, Parreira VF: Optoelectronic plethysmography: intra-rater and inter-rater reliability in healthy subjects. Respir Physiol Neurobiol 2013;189:473-476.

63 Reiterer F, Sivieri E, Abbasi S: Evaluation of bedside pulmonary function in the neonate: From the past to the future. Pediatr Pulmonol 2015;50:1039-1050.

64 Perego M, Zannin E, Marconi L, Dognini G, Ventura ML, Fedeli T, et al: Regional distribution of chest wall displacements in infants during high frequency oscillatory ventilation (HFOV). Eur Respir J 2015;46:PA1856.

65 Nozoe M, Mase K, Takashima S, Matsushita K, Kouyama Y, Hashizume H, et al: Measurements of chest wall volume variation during tidal breathing in the supine and lateral positions in healthy subjects. Respir Physiol Neurobiol 2014;193:38-42.

66 Wang HK, Lu TW, Liing RJ, Shih TTF, Chen SC, Lin KH: Relationship between chest wall motion and diaphragmatic excursion in healthy adults in supine position. J Formos Med Assoc 2009;108:577-586.

67 Romei M, Lo Mauro A, D’Angelo MG, Turconi AC, Bresolin N, Pedotti A, et al: Effects of gender and posture on thoraco-abdominal kinematics during quiet breathing in healthy adults. Respir Physiol Neurobiol 2010;172: 184-191.

68 Souza Mendes L, Hoffman Barbosa M, Silva Gabriel L, Ribeiro-Samora G, Freitas Fregonezi G, Dornelas Andrade A, et al: Influence of posture, gender and sex on breathing pattern and thoracoabdominal motion during quiet breathing in healthy subjects. Eur Respir J 2015;46:PA4218.

69 Muniz de Souza H, Rocha T, Campos SL, Brandão DC, Fink JB, Aliverti A, et al: Acute effects of different inspiratory efforts on ventilatory pattern and chest wall compartmental distribution in elderly women. Respir Physiol Neurobiol 2016;227:27-33.
70 Barcelar J de M, Aliverti A, Melo TLLDB, Dornelas CS, Lima CSFR, Reinaux CMA, et al: Chest wall regional volumes in obese women. Respir Physiol Neurobiol 2013;189:167173.

71 Filippelli M, Pellegrino R, Iandelli I, Misuri G, Rodarte JR, Duranti R, et al: Respiratory dynamics during laughter. J Appl Physiol 2001; 90:1441-1446.

72 Cossette I, Monaco P, Aliverti A, Macklem PT, Agarwal R, Yadav R, Anand S, Suri JC GJ: Chest wall dynamics and muscle recruitment during professional flute playing. Respir Physiol Neurobiol 2008;160:187-195.

73 Smith JA, Aliverti A, Quaranta M, McGuinness K, Kelsall A, Earis J, et al: Chest wall dynamics during voluntary and induced cough in healthy volunteers. J Physiol 2012;590:563574.

74 Paisani D de M, Lunardi AC, da Silva CCBM, Porras DC, Tanaka C, Carvalho CRF: Volume rather than flow incentive spirometry is effective in improving chest wall expansion and abdominal displacement using optoelectronic plethysmography. Respir Care 2013;58: 1360-1366

75 Illi SK, Hostettler S, Aliverti A, Spengler CM: Compartmental chest wall volume changes during volitional hyperpnoea with constant tidal volume in healthy individuals. Respir Physiol Neurobiol 2013;185:410-415.

76 O'Donnell DE: Hyperinflation, dyspnea, and exercise intolerance in chronic obstructive pulmonary disease. Proc Am Thorac Soc 2006;3:180-184.

77 Herth FJF, Slebos DiJ, Rabe KF, Shah PL: Endoscopic lung volume reduction: an expert panel recommendation. Respiration 2016;91: 241-250.

78 Aliverti A, Rodger K, Dellacà RL, Stevenson N, Lo Mauro A, Pedotti A, et al: Effect of salbutamol on lung function and chest wall volumes at rest and during exercise in COPD. Thorax 2005;60:916-924.

79 Jubran A, Tobin MJ: The effect of hyperinflation on rib cage-abdominal motion. Am Rev Respir Dis 1992;146:1378-1382.

80 Chihara K, Kenyon CM, Macklem PT: Human rib cage distortability. J Appl Physiol 1996;81:437-447.

81 Romagnoli I, Gigliotti F, Lanini B, Bruni GI, Coli C, Binazzi B, et al: Chest wall kinematics and breathlessness during unsupported arm exercise in COPD patients. Respir Physiol Neurobiol 2011;178:242-249.

82 Bianchi R, Gigliotti F, Romagnoli I, Lanini B, Castellani C, Grazzini M, et al: Chest wall kinematics and breathlessness during pursedlip breathing in patients with COPD. Chest 2004; 125:459-465.

83 Gagliardi E, Bruni G, Presi I: Thoraco-abdominal motion/displacement does not affect dyspnea following exercise training in COPD patients. Respir Physiol Neurobiol 2014;190: 124-130.
84 Bruni GI, Gigliotti F, Binazzi B, Romagnoli I, Duranti R, Scano G: Dyspnea, chest wall hyperinflation, and rib cage distortion in exercising patients with chronic obstructive pulmonary disease. Med Sci Sports Exerc 2012; 44:1049-1056.

85 Coutinho Myrrha MA, Vieira DSR, Moraes KS, Lage SM, Parreira VF, Britto RR: Chest wall volumes during inspiratory loaded breathing in COPD patients. Respir Physiol Neurobiol 2013;188:15-20.

86 Dellacà RL, Aliverti A, Pelosi P, Carlesso E, Chiumello D, Pedotti A, et al: Estimation of end-expiratory lung volume variations by optoelectronic plethysmography. Crit Care Med 2001;29:1807-1811.

87 Meric H, Calabrese P, Pradon D, Lejaille M, Lofaso F, Terzi N: Physiological comparison of breathing patterns with neurally adjusted ventilatory assist (NAVA) and pressure-support ventilation to improve NAVA settings. Respir Physiol Neurobiol 2014;195:11-18.

88 Fauroux B, Khirani S: Neuromuscular disease and respiratory physiology in children: putting lung function into perspective. Respirology 2014;19:782-791.

89 Lanini B, Masolini M, Bianchi R, Binazzi B, Romagnoli I, Gigliotti F, et al: Chest wall kinematics during voluntary cough in neuromuscular patients. Respir Physiol Neurobiol 2008;161:62-68.

90 D’Angelo MG, Romei M, Gandossini S, Bonato S, Brighina E, Lo Mauro A, et al: Advantages of the optoelectronic plethysmography in the evaluation of respiratory muscle function in DMD boys with scoliosis and spinal fusion. Gait Posture 2012;35:S7-S8.

91 Lo Mauro A, Romei M, D’Angelo MG, Aliverti A: Determinants of cough efficiency in Duchenne muscular dystrophy. Pediatr Pulmonol 2014;49:357-365.

92 Lo Mauro A, D’Angelo MG, Romei M, Gandossini S, Turconi AC, Pedotti A, et al: Chest wall kinematics during cough in Duchenne Muscular Dystrophy. Gait Posture 2012;35:S8.

93 Lissoni A, Aliverti A, Tzeng AC, Bach JR: Kinematic analysis of patients with spinal muscular atrophy during spontaneous breathing and mechanical ventilation. Am J Phys Med Rehabil 1998;77:188-192.

94 Cesario A, Dall'Armi V, Cusumano G, Ferri L, Margaritora S, Cardaci V, et al: Post-operative pulmonary rehabilitation after lung resection for NSCLC: a follow up study. Lung Cancer 2009;66:268-269.

95 Wilkens H, Weingard B, Lo Mauro A, Schena E, Pedotti A, Sybrecht GW, et al: Breathing pattern and chest wall volumes during exercise in patients with cystic fibrosis, pulmonary fibrosis and COPD before and after lung transplantation. Thorax 2010;65:808-814.

96 Nosotti M, Laviola M, Mariani S, Privitera E, Mendogni P, Nataloni IF, Aliverti A, et al: Variations of thoracoabdominal volumes after lung transplantation measured by optoelectronic plethysmography. Transplant Proc 2013;45:1279-1281. 
97 De Groote A, Van Muylem A, Scillia P, Cheron G, Verleden G, Paiva M, et al: Ventilation asymmetry after transplantation for emphysema: role of chest wall and mediastinum. Am J Respir Crit Care Med 2004;170: 1233-1238.

98 Cesario A, Ferri L, Galetta D, Pasqua F, Bonassi S, Clini E, et al: Post-operative respiratory rehabilitation after lung resection for non-small cell lung cancer. Lung Cancer 2007;57:175-180.

99 Bastianini F, Silvestri S, Magrone G, Gallotta E, Sterzi S: A preliminary efficacy evaluation performed by opto-electronic plethysmography of asymmetric respiratory rehabilitation. Conf Proc IEEE Eng Med Biol Soc 2009;2009:849-852.

100 Elshafie G, Aliverti A, Pippa L, Kumar P, Kalkat M, Naidu B: Surgery corrects asynchrony of ribcage secondary to extra-thoracic tumor but leads to expiratory dysfunction during exercise. J Cardiothorac Surg 2015; 10:187.

101 Binazzi B, Innocenti Bruni G, Coli C, Romagnoli I, Messineo A, Lo Piccolo R, et al: Chest wall kinematics in young subjects with pectus excavatum. Respir Physiol Neurobiol 2012;180:211-217.

102 Redlinger RE, Kelly RE, Nuss D, Goretsky M, Kuhn MA, Sullivan K, et al: Regional chest wall motion dysfunction in patients with pectus excavatum demonstrated via optoelectronic plethysmography. J Pediatr Surg 2011;46:1172-1176.

103 Ferrigno G, Carnevali P: Principal component analysis of chest wall movement in selected pathologies. Med Biol Eng Comput 1998;36:445-451.

104 Romagnoli I, Gigliotti F, Galarducci A, Lanini B, Bianchi R, Cammelli D, et al: Chest wall kinematics and respiratory muscle action in ankylosing spondylitis patients. Eur Respir J 2004;24:453-460.

105 Remiche G, Lo Mauro A, Tarsia P, Ronchi D, Bordoni A, Magri F, et al: Postural effects on lung and chest wall volumes in late onset type II glycogenosis patients. Respir Physiol Neurobiol 2013;186:308-314.

106 Frazão M, Cabral E, Lima I, Resqueti V, Florêncio $\mathrm{R}$, Aliverti $\mathrm{A}$, et al: Assessment of the acute effects of different PEP levels on respiratory pattern and operational volumes in patients with Parkinson's disease. Respir Physiol Neurobiol 2014;198:42-47.
107 Brandão DC, Lage SM, Britto RR, Parreira VF, de Oliveira WA, Martins SM, et al: Chest wall regional volume in heart failure patients during inspiratory loaded breathing. Respir Physiol Neurobiol 2012;180:269-274.

108 Mezzani A, Agostoni P, Cohen-Solal A, Corrà $\mathrm{U}$, Jegier $\mathrm{A}$, Kouidi $\mathrm{E}$, et al: Standards for the use of cardiopulmonary exercise testing for the functional evaluation of cardiac patients: a report from the Exercise Physiology Section of the European Association for Cardiovascular Prevention and Rehabilitation. Eur J Cardiovasc Prev Rehabil 2009; 16: 249-267.

109 Dickinson J, McConnell A, Ross E, Brown P, Hull J: The BASES Expert Statement on Assessment and Management of Non-asthma Related Breathing Problems in Athletes. 2015. http://www.bases.org.uk/write/Documents/TSES_AUTUMN_2015_P8-9 (PAGES).pdf.

110 Dickinson J, Whyte G, McConnell A: Inspiratory muscle training: a simple cost-effective treatment for inspiratory stridor. $\mathrm{Br} \mathrm{J}$ Sports Med 2007;41:694-695; discussion 695.

111 Layton AM, Garber CE, Basner RC, Bartels $\mathrm{MN}$ : An assessment of pulmonary function testing and ventilatory kinematics by optoelectronic plethysmography. Clin Physiol Funct Imaging 2011;31:333-336.

112 Layton AM, Garber CE, Thomashow BM, Gerardo RE, Emmert-Aronson BO, Armstrong HF, et al: Exercise ventilatory kinematics in endurance trained and untrained men and women. Respir Physiol Neurobiol 2011;178:223-229.

113 Layton AM, Moran SL, Garber CE, Armstrong HF, Basner RC, Thomashow BM, et al: Optoelectronic plethysmography compared to spirometry during maximal exercise. Respir Physiol Neurobiol 2013;185: 362-368.

114 Bianchi R, Gigliotti F, Romagnoli I, Lanini B, Castellani C, Binazzi B, et al: Patterns of chest wall kinematics during volitional pursed-lip breathing in COPD at rest. Respir Med 2007;101:1412-1418.

115 Rocha T, Souza H, Brandão DC, Rattes C, Ribeiro L, Campos SL, et al: The manual diaphragm release technique improves diaphragmatic mobility, inspiratory capacity and exercise capacity in people with chronic obstructive pulmonary disease: a randomised trial. J Physiother 2015;61:182189.
116 Borges-Santos E, Wada JT, da Silva CM, Silva RA, Stelmach R, Carvalho CR, et al: Anxiety and depression are related to dyspnea and clinical control but not with thoracoabdominal mechanics in patients with COPD. Respir Physiol Neurobiol 2015;210:1-6.

117 Lima I, Fregonezi G, Basoudan N, Sales AT, Reid D: Chest wall volumes during constant compared to incremental cycle ergometer tests in chronic obstructive pulmonary disease (COPD) patients: a systematic review and meta-analysis. Eur Respir J 2015;46: PA2255.

118 Romei M, D’Angelo MG, Lo Mauro A, Gandossini S, Bonato S, Brighina E, et al: Low abdominal contribution to breathing as daytime predictor of nocturnal desaturation in adolescents and young adults with $\mathrm{Du}$ chenne Muscular Dystrophy. Respir Med 2012;106:276-283.

119 D’Angelo MG, Romei M, Lo Mauro A, Marchi E, Gandossini S, Bonato S, et al: Duchenne muscular dystrophy and optoelectronic plethysmography: A longitudinal study of respiratory function (P1.12). Neuromuscul Disord 2011;21:645.

120 Bonato S, D’Angelo MG, Gandossini S, Romei M, Colombo D, Turconi AC, et al: Optoelectronic Plethysmography for respiratory assessment in Muscular Duchenne Dystrophy (P03.5). Eur J Paediatr Neurol 2011; 15:S43.

121 Boudarham J, Pradon D, Prigent H, Falaize L, Durand M-CC, Meric H, et al: Optoelectronic plethysmography as an alternative method for the diagnosis of unilateral diaphragmatic weakness. Chest 2013;144:887895.

122 Meric H, Falaize L, Pradon D, Orlikowski D, Prigent H, Lofaso F: 3D analysis of the chest wall motion for monitoring late-onset Pompe disease patients. Neuromuscul Disord 2016;26:146-152.

123 Vogiatzis I, Aliverti A, Golemati S, Georgiadou $\mathrm{O}$, Lo Mauro A, Kosmas E, et al: Respiratory kinematics by optoelectronic plethysmography during exercise in men and women. Eur J Appl Physiol 2005;93: 581-587.

124 Lissoni A, Aliverti A, Molteni F, Bach JR: Spinal muscular atrophy: kinematic breathing analysis. Am J Phys Med Rehabil 1996; 75:332-339. 